\title{
Effects of synthetic pyrethroids Cyfluthrin and Fenvalerate on Nucleic acid contents of fresh water fish Gambusia affinis
}

\author{
S. Mohammed Ghouse \\ Department of Zoology, Osmania College, Kurnool, Andhra Pradesh, India \\ Corresponding Author: syed0002001@gmail.com, Mobile: 9501603265
}

Available online at: www.isroset.org

Received: 22/May/2019, Accepted: 12/Jun/2019, Online: 30/Jun/2019

\begin{abstract}
India is a country with more than $60-70 \%$ of its population dependent on agriculture. Rapid industrialization and successful green, white and blue revolutions have necessitated a large variety of chemicals/pesticides usage resulting environmental pollution which has become not only a national but a global problem. Fish occupy a prominent position in the field of aquatic toxicology and have been employed in studies concerning ecological health. In the present investigation two synthetic pyrethroids were selected namely Cyfluthrin and Fenvalerate to evaluate their toxicity on Gambusia affinis. In the present study there is significant decline in DNA content in the gill, liver and kidney tissues is observed, when the fish Gambusia affinis is exposed to the cyflthrin and fenvalerate. Decreases in the DNA content due to inhibition of the enzymes in DNA synthesis. The declines in RNA level in treated fish due to obstruction in RNA synthesis. Resulting in the swelling and chromatolysis of Nissle bodies which are rich in RNA. Pesticides may influence directly or modify DNA, other cellular process associated with the integrity of the genome.
\end{abstract}

Keywords : India, agro-based country, pesticides, fish, DNA, RNA decline

\section{INTRODUCTION}

India is primarily an agro-based country with more than $60-70 \%$ of its population dependent on agriculture. Rapid industrialization and successful green, white and blue revolutions have necessitated a large variety of chemicals usage resulting environmental pollution which has become not only a national but a global problem. More than $30 \%$ of its agricultural productivity is lost due to the to pests .Excess use of insecticides to get more agriculture yield and spraying of pesticides improperly in agricultural fields cause these chemicals to accumulate in the field, along with rain water these pesticides finally reach the natural water systems like ponds, streams, lakes and rivers., it will ultimately lead to alteration in the ecosystem . [1].. Pesticides are hazardous to the biodiversity including the man. The synthetic pyrethroids act as excitatory nerve poisons, thought to poison by interfering with the ionic permeability of nerve cell membranes. Through a better understanding of toxicology and toxicity testing in relation to these biochemical parameters in non-target organisms like fish we may be able to contribute to such an inquiry and hence the present work.

Various pesticides that are commonly used in pest control programmes are generally grouped under 4 heads: They are:

(1) chlorinated hydrocarbon, the 1st generation insecticides (aldrin, DDT, chlordane, dicofol (kelthane), dieldrin, endrin, endosulphon, heptachlor, kepone, lindane, methoxychlor, mirex, and toxaphene];

(2) the second generation organophosphate insecticides include, parathion, malathion, diazinon, monocrotophos etc.,

(3) the third generation insecticides are exemplified by carbamates like, carbaryl, carbofuran, propuxur etc., and

(4) the fourth generation insecticides are the pyrethroids example, Allethrin

Fish occupy a prominent position in the field of aquatic toxicology and have been employed in studies concerning ecological health. After China, India is the second largest producer of pesticides in Asia and with $12^{\text {th }}$ ranks globally. India started the production of BHC in 1952 with the establishment of a plant near Calcutta. The main use of pesticides in India is for cotton crops $(45 \%)$, followed by paddy and wheat. In India the usage pattern of the of pesticide is different from the world in general. Globally $44 \%$ of the pesticide is used as inscecticide, where as in india $76 \%$ of the pesticide used as insecticide . [2]. The potential toxicity of the pesticide will lead to tissue damage and change in behaviour . [3,4]. 
The detoxification mechanism present in the body of the organism will work to get rid of foreign substances. If the concentration of toxic substance is higher it results in damage at cellular or even at molecular level, which leads to behavioral, physiological, pathological and biochemical disorders that may prove fatal conditions to aquatic life $[5,6,7,8]$. The protection of the genetic diversity in natural populations maintained through DNA integrity [9]. DNA and RNA damage , health assessment of organism can be done by detection of structural/functional disturbances in the DNA [10]. The main purpose of this study is to evaluate the toxicity of cyfluthrin and fenvalerate on, Gambusia affinis with reference nucleic acid content.

\section{MATERIALS AND METHODS}

\section{Collection, maintenance and acclimatization of experimental fish}

Adult fresh water fishes Gambusia affinis with weight $(0.7-1.5 \mathrm{gm})$, length $(2.3-3.2 \mathrm{~cm})$ from both sexes were selected randomly for the experimental studies were collected from water bodies and fisheries department of Kurnool district, Andhra Pradesh, India. The collected fish were transported in polythene bags filled with half water with least disturbance . They are kept in aquarium tanks containing well aerated de-chlorinated water to acclimatize to the laboratory conditions, with physicochemical characteristics : temperature $24 \pm 2^{\circ} \mathrm{C}$, pH $7.1 \pm 0.2$ at $24^{\circ} \mathrm{C}$, dissolved oxygen $9.6 \pm 0.8 \mathrm{mg} / \mathrm{L}$, carbon dioxide $6.3 \pm 0.4$ $\mathrm{mg} / \mathrm{L}$, total hardness $23.4 \pm 3.4 \mathrm{mg}$ as $\mathrm{CaCO}_{3} / \mathrm{L}$, phosphate $0.39 \pm 0.002 \mu \mathrm{g} / \mathrm{L}$, salinity in different cement tanks for one week . To prevent fungal infection the fish tanks were washed with potassium permanganate solution. Dead fish were removed as soon as possible to avoid water fouling.

Fishes were fed daily on commercial fish food. The unused food is removed daily and water was renewed daily .Test fishes were screened critically for any signs of stress, disease, physical damage and mortality. Injured, severely, diseased fishes were discarded. The fishes were exposed to sublethal concentrations for treated and control period of 96 hours. A control group was maintained with identical environment. The toxicant water as well as normal water is renewed every day. The fish were sacrificed from both experimental and control groups on 96 hours.

\section{Selection of pesticides}

In the present investigation two synthetic pyrethroids were selected namely Cyfluthrin and Fenvalerate.

\section{Cyfluthrin}

As per the reports pyrethroids are extremely toxic to fish and to some beneficial aquatic arthropods like lobster and shrimp. Cyfluthrin first registered by EPA in 1987, cyfluthrin is found in both restricted use (RUP) and general use insecticides [11]. Cyfluthrin is clear liquid, dark amber in color, with an oily to pasty consistency, and has a faint aromatic solvent odor at room temperature. Cyfluthrin, cyano (4-fluoro-3- phenoxyphenyl) methyl-3-(2,2 dichloroethenyl) -2,2dimethylcyclopropanecarboxylate) is a broad spectrum synthetic type II pyrethroid insecticide.

Cyfluthrin acts as contact and stomach poison it attacks the nervous system; a nonsystemic insecticide used to control chewing and sucking insects and also in public health situations [12]. Insects when in come in contact with cyfluthrin die of starvation and desiccation, ceasing to feed. It is extensively used in agricultural crops, stored products, public health situations (i.e. cockroaches, mosquitoes, and flies), ornamentals, turf, and domestic pests. Insects like cockroaches, ants, grain beetles, silverfish, , fleas, flies, European corn borer, Colorado potato beetle, and many others are the main target of cyfluthrin use. $[13,14] .$.

Cyfluthrin act on non target organisms. The toxicity of cyfluthrin observed in various fish species is $0.68 \mathrm{mg} / \mathrm{L}$ inrainbow trout (Oncorhyncus mykiss), $1.5 \mathrm{mg} / \mathrm{L}$ in bluegill (Lepomis macrochirus), $22 \mathrm{mg} / \mathrm{L}$ in carp (Cyprinus carpio), 3.2mg/L in golden orfe (Leuciscus idus), channel catfish (Ictalurus punctatus) and sheepshead minnow (Cyprinodon variegatus), 25.82mg/L for $48 \mathrm{~h}$ [15]. and $21.07 \mathrm{mg} / \mathrm{L}$ for $72 \mathrm{~h}$ to Nile tilapia fry (Oreochromis niloticus L. 1758) [16]. Cyfluthrin accumulation in the flesh of Tilapia nilotica, exposed to a sublethal dose of $0.001 \mathrm{mg} / \mathrm{L}$, was $0.009 \mathrm{mg} / \mathrm{L}$ after 5 days of application [17]. also pyrethroid toxicology in mammals, birds, amphibians and both terrestrial and aquatic invertebrates.reviewed. [15,18].

Cyfluthrin causes oxidative damage in aquatic organisms resulting in the damage of essential cell components like DNA, protein, lipids and lipoproteins, caused by free oxygen radicals [19]. Thus inducing loss of cell integrity and functional alteration of cell receptors and enzymes [20]. The products which has cyfluthrin are classified as acute Toxicity Category II (bearing the signal word "Warning") or Toxicity Category I (bearing the signal word "Danger") by EPA based on its potential ability to cause eye damage [21]. 


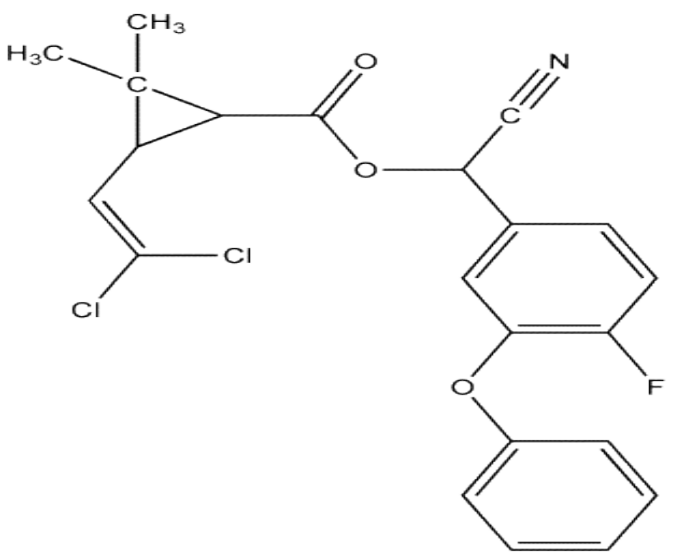

Figure 1. Cyfluthrin cyano (4-fluoro-3-phenoxyphenyl)methyl-3-(2,2- dichloroethenyl)-2,2-dimethyl-cyclopropanecarboxylate

\section{Fenvalerate}

Fenvalerate, is a clear viscious yellow liquid with a mild odor, a synthetic pyrethroid. First developed in 1974 by Sumitomo Chemical Co. of Japan (Sumicidin ${ }^{\mathrm{TM}}$ ), is most widely used in agricultural crops such as cotton, paddy, jowar, maize, soyabean, tomato, lady's finger, cauliflower, tobacco and tea. The biology of the non target species is affected by the use of insecticide along with pests. [22,23,24,25,26,27,28]. In India, the pesticide is used primarily to control pests of cotton and vegetables [29].

The $\mathrm{LC}_{50}$ for $48 \mathrm{~h}$ of fenvalerate exposure to carp, C. carpio $(8 \mathrm{~cm})$ at $\mathrm{p} \mathrm{H} \mathrm{8-8.88}$ was reported to be $0.0210 \mathrm{mgL}-1$ [30]. Acute toxicity $\left(\mathrm{LC}_{50}\right)$ calculated over $96 \mathrm{~h}$ for catla fingerlings $(2.02 \pm 0.1 \mathrm{~g})$ was observed to be $6 \mu \mathrm{gL}-1$ [31]. LC50 value of fenvalerate at 96 hours to Channa punctatus $(20 \pm 3 \mathrm{~g})$ is reported to be $2.13 \mu \mathrm{g}$ L-1 [32]. Fish have a poor ability to metabolise and excrete fenvalerate [33]. and thus are susceptible to even minute concentration of the pesticide.

Fenvalerate have half life of approximately two to four weeks in mineral and organic soils [34]. Deltamethrin is more persistent with a half-life of more than two months in soils [35]. . Fenvalerate is recently developed synthetic pyrethroids, which is highly toxic to fish but shows very low avian and mammalian toxicity. [36,37].

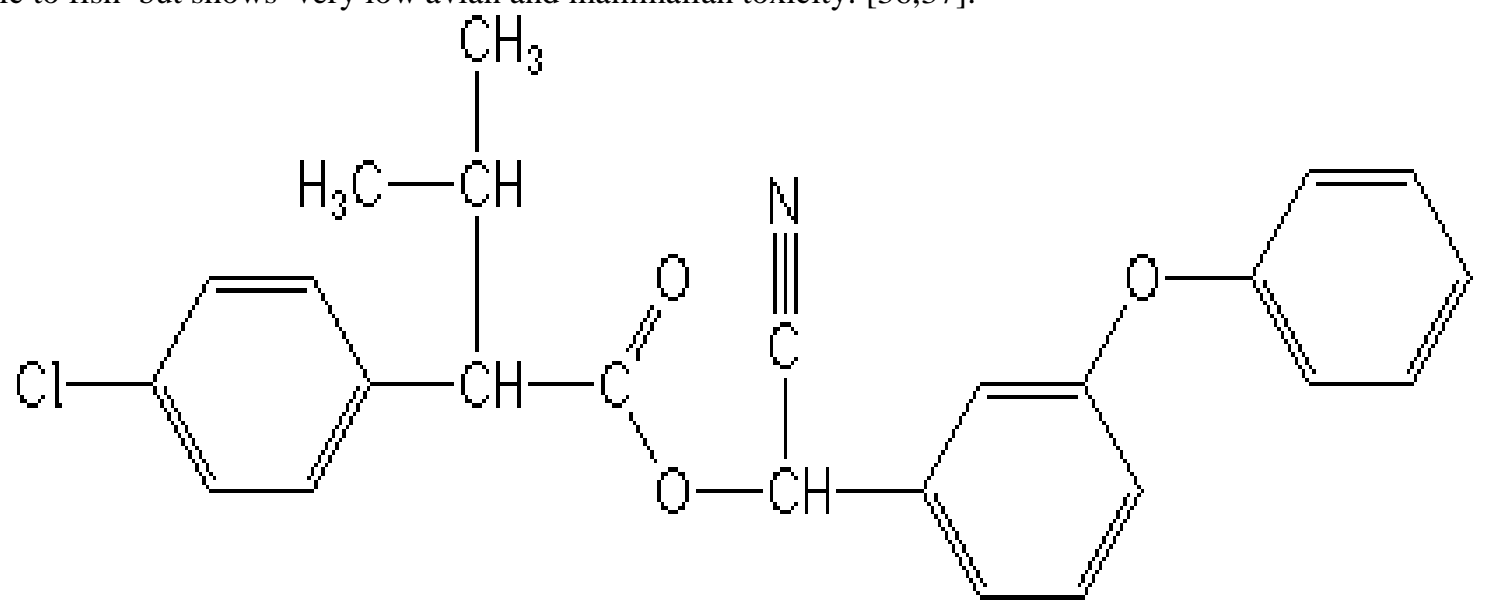

Figure 2. IUPAC name : (RS)-a-cyano-3-phenoxybenzyl (RS)-2-(4-chlorophenyl)-3-methylbutyrate Chemical Abstracts name : cyano (3-phenoxyphenyl)methyl 4-chloro-a-(1-methylethyl) benzene acetate

\section{Experimental design Group 1}

Group 2

Group 3
: Fish exposed to tap water observed for 24 to 96

Hours (Untreated control).

: Fish exposed to sublethal concentration of cyfluthrin of 24 to 96 hours.

: Fish exposed to sublethal concentration of fenvalerate of 24 to 96 hours. 


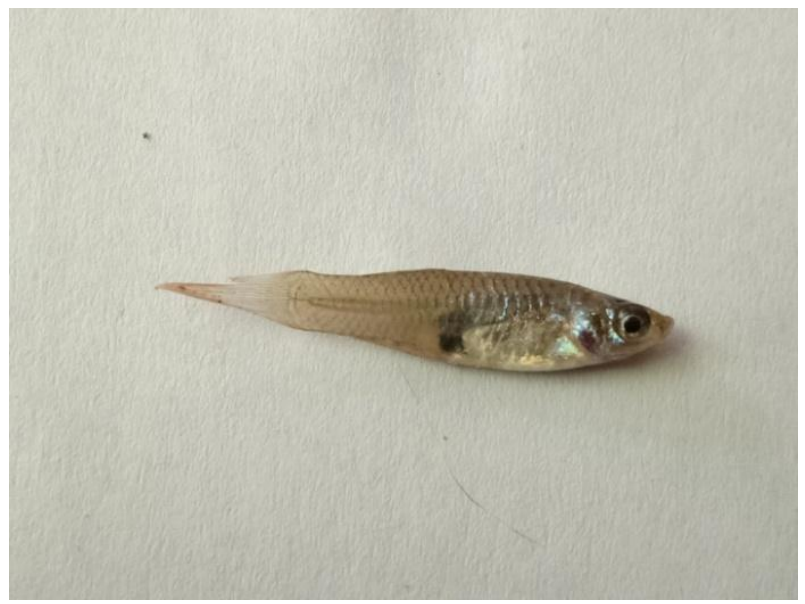

Figure 3. Gambusia affinis

\section{Calculation of $\mathrm{LC}_{50}$}

The $\mathrm{LC}_{50}$ values were obtained by probit analysis method based percentage of test animals surviving at concentrations that were lethal to more than half and less than half of the test subjects [38].

Acute toxicity studies : The toxicity studies will conducted by using the technical grade formulation available formulation of Fenvalerate and Cyfluthrin. Solutions of desired concentrations were prepared in $95 \%$ acetone to get the stock solution as well as working solution as $100 \mathrm{mg} / 100 \mathrm{ml}$ and $1 \mathrm{mg} / 1 \mathrm{ml}$ of toxicant chemical Fenvalarate and Cyfluthrin in both technical formulation use of acetone in control as recommended by EPA will be followed.

The the acclimatized fishes were kept in cement tanks and ten fishes in two groups control fishes will be kept in dechlorinated water only. Each set of experiment was replicated six times. Mortality was recorded every $24 \mathrm{~h}$ during the observation period of 96h.

The LC 50 values were calculated for Gambusia affinis exposed to of cyfluthrin and fenvalerate at 3, 6,12,24, 48, 72 and 96 hours and they were found to be $36.12,34.41,33.76,31.32,28.97,26.69,24.73 \boldsymbol{\mu g} / \mathbf{L}$ - cyfluthrin and $19.67,18.98,17.29$, $16.98,15.93,14.75,13.87 \mu \mathrm{g} / \mathrm{L}$ - fenvalerate respectively. The toxicity curve showed the mode of action and the toxicity of cyfluthrin and fenvalerate for different concentrations at different periods. A similar result with regard to fenvalerte toxicity in Gambussia affinis, the $\mathrm{LC}_{50}$ value of $15.0 \mu \mathrm{g} / \mathrm{L}(48 \mathrm{~h})$ was reported . [39].

In the present study, it was observed that the mortality rate increased with the higher concentration of cyfluthrin and fenvalerate over a short period of time and diminished with decreasing concentration during the subsequent hours of treatment.

\section{Statistical Analysis}

The data obtained from the quantitative study were expressed as the mean \pm S.E. The mean values were calculated from 6 individual observations. $\mathrm{P}$ - values were calculated by the students ' $\mathrm{t}$ ' test.The two mean values obtained were considered significant from each other with standard error.

\section{Estimation of nucleic acids}

Nucleic acids were extracted from the tissues by the method described by Schneider (1957). [40].

Principle: Nucleic acids are separated from the other tissue components by exploiting their property of preferential solubility in hot trichloroacetic acid (TCA) solution.

Procedure: Known weight of tissue was rinsed finely and homogenized in distilled water, to homogenate $5 \mathrm{ml}$ of $10 \%$ ice cold TCA was added and was kept in an ice bath for 30 minutes to allow complete precipitation of proteins and nucleic acids. The mixture was centrifuged and the precipitate was later treated with absolute alcohol and centrifuged to remove lipid materials. The precipitate free of lipids was suspended in required amount of 5\% TCA and placed in a water bath maintained at $90^{\circ} \mathrm{C}$ for 15 minutes with occasional stirring which facilitates the quantitative separation of nucleic acids from the precipitated proteins. This was centrifuged and the supernatant was used for the estimation of Ribonucleic acid (RNA) and Deoxyribonucleic acid (DNA). [41]. 


\section{Estimation of DNA}

Principle: Estimation of DNA was performed by using diphenylamine reagent (Schneider, 1957). This method is based on the property of deoxyribose moiety of DNA to form hydroxy laevulaldehyde in TCA solution. This reacts with diphenylamine to give a coloured complex. The intensity of colouration is presumed to be proportional to the pentose (deoxyribose) concentration in the DNA hydrolyzate. Total DNA content was expressed as $\mathrm{mg} / 100 \mathrm{~g}$ wet tissue.

Reagents A. Dische's diphenylamine reagent $1 \mathrm{~g}$ of diphenylamine was dissolved in $100 \mathrm{ml}$ of glacial acetic acid. After adding $2.75 \mathrm{ml}$ of Conc. H2SO4, the solution was mixed and stored in dark. B. Standard DNA Solution Freshly prepared by dissolving $100 \mathrm{mg}$ of commercially available DNA with $100 \mathrm{ml}$ of distilled water.

Procedure: $1 \mathrm{ml}$ of isolated nucleic acid TCA hydrolyzate was taken and mixed well with $0.5 \mathrm{ml}$ of perchloric acid. The solution was kept for boiling after adding $2 \mathrm{ml}$ of reagent $\mathrm{A}$. Boiling was done in water bath for 10 minutes. The solution was then cooled under tap water and optical density was measured at $565 \mathrm{~nm}$ against blank. [41].

\subsubsection{Estimation of RNA}

Principle : Total RNA content was estimated by the methods of Schneider (1957) using orcinol reagent. The ribose moiety of RNA in the TCA extract is converted to furfural which condenses with orcinol to yield a blue coloured complex. The colour intensity is presumed to be proportional to RNA concentration in the extract. Total RNA content was expressed as $\mathrm{mg} / 100 \mathrm{~g}$ wet tissue.

Reagents A. Orcinol reagent $500 \mathrm{ml}$ of $30 \% \mathrm{HCl}$ was taken and $1 \mathrm{~g}$ of orcinol was dissolved well in it. 4-5 ml of $10 \%$ ferric chloride was added and mixed in it. The solution was stored in a brown bottle. B. Standard RNA Solution dissolved $100 \mathrm{mg}$ of RNA in $100 \mathrm{ml}$ of distilled water

Procedure: $2 \mathrm{ml}$ of nucleic acid TCA extract was taken and added with $2 \mathrm{ml}$ of orcinol reagent. The solution was mixed and kept for boiling for 20 minutes and cooled thereafter. Absorbance was read at $670 \mathrm{~nm}$ in UV- spectrophotometer. [41].

\section{RESULTS}

\section{Deoxyribonucleic acid (DNA) \\ Gill}

The content of DNA in gill tissues are decreased significantly in the present study when Gambusia affinis exposed to cyfluthrin ( group-2) and fenvalerate ( group-3), when compared with the control group. The percentage of decrease over the control with cyfluthrin ( group-2) are - 16.73, - 22.22, - 27.08, -32.35 for 24, 48, 72 and 96 hours respectively. Whereas in group-3 percent decreased in DNA content over the control are -20.21, 30.05, - 39.19, - 43.94 for 24, 48, 72 and 96 hours respectively. The levels of DNA content for 3 groups are recorded are statistically significant at $1 \%$ and $5 \%$ levels (Table 1: Fig.4).

\section{Liver}

The observed value of DNA content in the liver tissues of Gambusia affinis fish exposed to cyfluthrin ( group-2) and fenvalerate ( group-3) showed a decline, when compare with the control group. The percent decline in DNA content with cyfluthrin ( group-2) are- 19.48, - 27.88, - 30.37, - 38.63 for 24, 48, 72 and 96 hours respectively. The percent decrease in DNA content with fenvalerate ( group-3) are $-23.84,-32.38,-45.33$ for $24,48,72$ and 96 hours respectively. The levels of DNA content for 3 groups are recorded are statistically significant at $1 \%$ and $5 \%$ levels ((Table 1: Fig.4).

\section{Kidney}

The DNA content of the in the tissues of kidney in Gambusia affinis fish exposed to cyfluthrin (group-2) and fenvalerate (group-3) decreased in comparison with control group. The percentage of alterations are -9.92, - 16.83, - 19.62, - 23.90 for $24,48,72$ and 96 hours respectively in fish exposed to cyfluthrin ( group-2) .

The percentage of alterations in fish exposed to fenvalerate ( group-3) are - 11.26, - 19.57, - 28.07, - 34.39 for $24,48,72$ and 96 hours respectively. The levels of DNA content for 3 groups are recorded are statistically significant at $1 \%$ and 5\% levels (Table 1: Fig.4). 
Table 1 : Variations of Deoxyribonucleic acid (DNA) (mg/g wet. wt of tissue) content in fresh water fish Gambusia affinis exposed to Cyfluthrin and Fenvalerate for 96 hours

\begin{tabular}{|c|c|c|c|c|c|}
\hline \multirow{2}{*}{ Tissues } & \multirow[t]{2}{*}{ Groups } & \multicolumn{4}{|c|}{ Hours of exposure } \\
\hline & & 24 & 48 & 72 & 96 \\
\hline \multirow[t]{2}{*}{ Gill } & $\begin{array}{l}\text { Group -II- Cyfluthrin } \\
\% \text { COC }\end{array}$ & $\begin{array}{c}2.756 * \pm 0.065 \\
\%-16.73\end{array}$ & $\begin{array}{c}2.575 * * \pm 0.064 \\
\%-22.22\end{array}$ & $\begin{array}{c}2.415^{* *} \pm \\
0.065 \\
\%-27.08\end{array}$ & $\begin{array}{c}2.241 * * \pm 0.066 \\
\%-32.35\end{array}$ \\
\hline & $\begin{array}{l}\text { Group -III- Fenvalerate } \\
\% \text { COC }\end{array}$ & $\begin{array}{l}2.641 * \pm 0.065 \\
\%-20.21\end{array}$ & $\begin{array}{c}2.316 * * \pm 0.064 \\
\%-30.05\end{array}$ & $\begin{array}{c}2.014 * * \pm \\
0.065 \\
\%- \\
39.19 \\
\end{array}$ & $\begin{array}{c}1.857 * * \pm 0.066 \\
\%-43.94\end{array}$ \\
\hline \multirow{2}{*}{ Liver } & Group-I Control & $5.721 \pm 0.674$ & $5.722 \pm 0.672$ & $5.722 \pm 0.671$ & $5.723 \pm 0.669$ \\
\hline & $\begin{array}{l}\text { Group -III- Fenvalerate } \\
\% \text { COC }\end{array}$ & $\begin{array}{c}4.357 * \pm 0.733 \\
\%-23.84\end{array}$ & $\begin{array}{c}3.869 * * \pm 0.737 \\
\%-32.38\end{array}$ & $\begin{array}{c}3.128 * * \pm \\
0.739 \\
\%- \\
45.33\end{array}$ & $\begin{array}{c}2.567 * * \pm 0.740 \\
\%-55.14\end{array}$ \\
\hline \multirow{3}{*}{ Kidney } & Group-I Control & $4.412 \pm 0.049$ & $4.413 \pm 0.047$ & $4.413 \pm 0.046$ & $4.414 \pm 0.048$ \\
\hline & $\begin{array}{l}\text { Group -II- Cyfluthrin } \\
\% \text { COC }\end{array}$ & $\begin{array}{c}3.974 * \pm 0.670 \\
\%-9.92\end{array}$ & $\begin{array}{c}3.670 * \pm 0.672 \\
\%-16.83\end{array}$ & $\begin{array}{c}3.547 * * \pm \\
0.674 \\
\%-19.62\end{array}$ & $\begin{array}{c}3.359 * * \pm 0.680 \\
\%-23.90\end{array}$ \\
\hline & $\begin{array}{l}\text { Group -III- Fenvalerate } \\
\% \text { COC }\end{array}$ & $\begin{array}{c}3.915 * \pm 0.542 \\
\%-11.26\end{array}$ & $\begin{array}{c}3.549 * \pm 0.546 \\
\%-19.57\end{array}$ & $\begin{array}{c}3.174 * \pm 0.550 \\
\%- \\
28.07\end{array}$ & $\begin{array}{c}2.896 * \pm 0.553 \\
\%-34.39\end{array}$ \\
\hline
\end{tabular}

Values are mean \pm S.E Mean of six individual observations and student t-test. significant at $* \mathrm{P}<0.05 ;$ Significant at $* \mathrm{P}<0.01$ levels $(+,-)$ denotes decreased and increased .\% COC (change over control);

Fig. 4 : Changes in the content of Deoxyribonucleic acid (DNA) (mg/g wet. wt of tissue) in fresh water fish Gambusia affinis exposed to Cyfluthrin and Fenvalerate for 96 hours

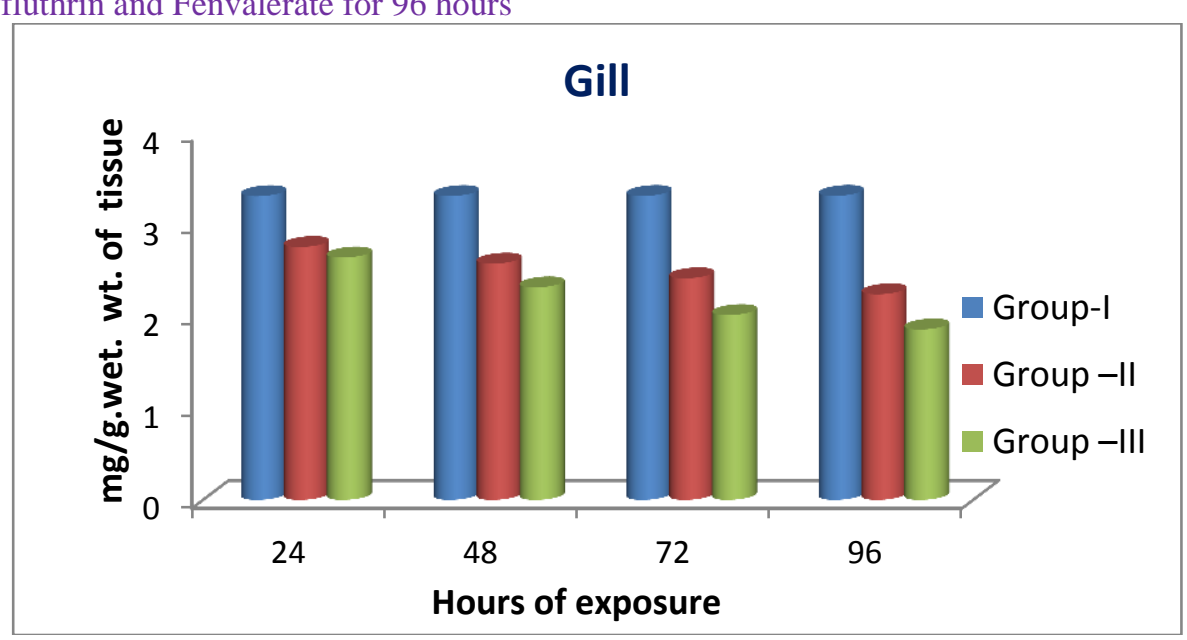




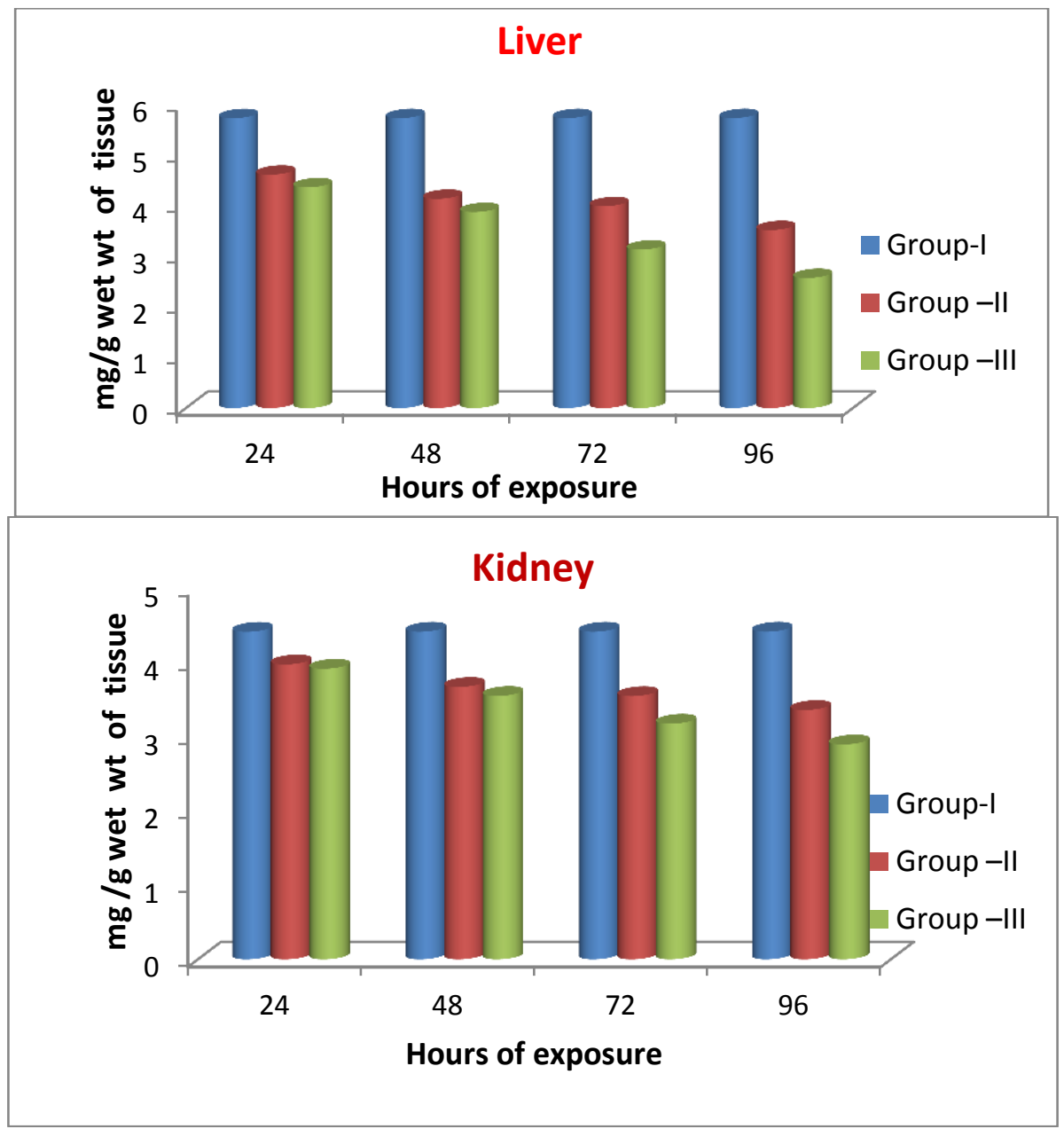

Table 2 : Variations of Ribonucleic acid (RNA) (mg/g wet. wt of tissue) content in fresh water fish Gambusia affinis exposed to Cyfluthrin and Fenvalerate for 96 hours

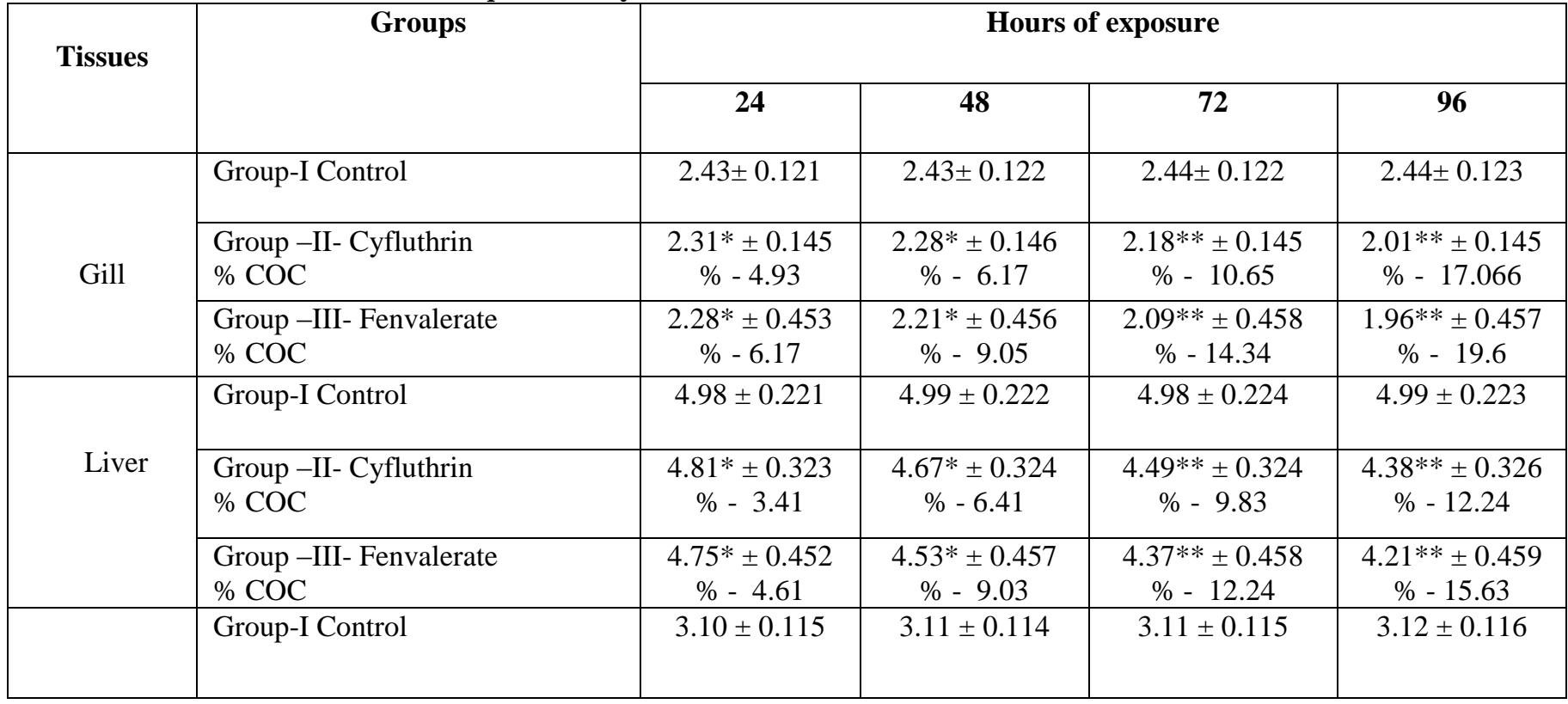




\begin{tabular}{|c|l|c|c|c|c|}
\hline Kidney & Group -II- Cyfluthrin & $3.01 * \pm 0.145$ & $2.93 * \pm 0.147$ \\
& $\%$ COC & $\%-2.90$ & $2.84 * * \pm 0.148$ & $2.74 * * \pm 0.149$ \\
& \% & $2.98 * \pm 0.261$ & $2.90 * \pm 0.263$ & $2.81 * * \pm 0.267$ & $2.69 * * \pm 0.298$ \\
& Group -III- Fenvalerate & $\%-4.18$ & $\%-6.75$ & $\%-9.64$ & $\%-13.78$ \\
\hline
\end{tabular}

Values are mean \pm S.E Mean of six individual observations and student t-test. significant at $* \mathrm{P}<0.05$; Significant at $* \mathrm{P}<0.01$ levels(+,- ) denotes decreased and increased .\%COC (change over control);

\section{Ribonucleic acid (RNA)}

Gill

In the present study RNA content in the tissues of gill are decreased in the present study Gambusia affinis exposed to cyfluthrin ( group-2) and fenvalerate ( group-3), when compared with the control group. The percentage of decrease over the control with cyfluthrin ( group-2) are - 4.93, - 6.17, -10.65, - 17.066, for 24, 48, 72 and 96 hours respectively. Whereas in group-3 percent decreased in RNA content over the control are - 6.17, - 9.05, - 14.34, - 19.6 for 24, 48, 72 and 96 hours respectively. The levels of RNA content for 3 groups are recorded are statistically significant at $1 \%$ and $5 \%$ levels (Table 2 : Fig.5).

Liver

The observed value of RNA content in the liver tissues of Gambusia affinis fish exposed to cyfluthrin ( group-2) and fenvalerate ( group-3) showed a decline, when compare with the control group. The percent decline in RNA content with cyfluthrin ( group-2) are - 3.41, - 6.41, - 9.83, - 12.24 for 24, 48, 72 and 96 hours respectively. The percent decrease in RNA content with fenvalerate (group-3) are - 4.61, - 9.03, - 12.24, - 15.63 for 24, 48, 72 and 96 hours respectively. The levels of RNA content content for 3 groups are recorded are statistically significant at $1 \%$ and 5\% levels(Table 2: Fig.5).

\section{Kidney}

In the present investigation the RNA content of the in the tissues of kidney in Gambusia affinis fish exposed to cyfluthrin ( group-2) and fenvalerate ( group-3) decreased in comparison with control group. The percentage of alterations are $-2.90,-5.78,-8.68,-12.17$ for $24,48,72$ and 96 hours respectively in fish exposed to cyfluthrin ( group-2).

The percentage of alterations in fish exposed to fenvalerate (group-3) are $-4.18,-6.75,-9.64,-13.78$ for 24 , 48, 72 and 96 hours respectively. The levels of RNA content content for 3 groups are recorded are statistically significant at $1 \%$ and $5 \%$ levels (Table 2: Fig.5).

Fig. 5 : Changes in the content of Ribonucleic acid (RNA) (mg/g wet. wt of tissue) in fresh water fish Gambusia affinis exposed to Cyfluthrin and Fenvalerate for 96 hours

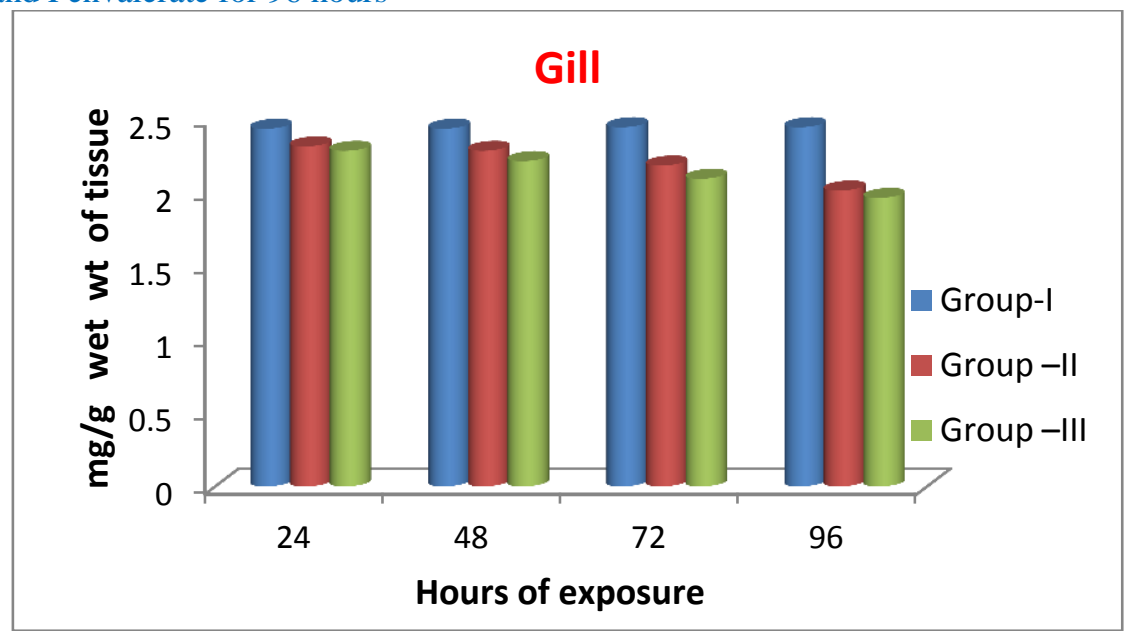




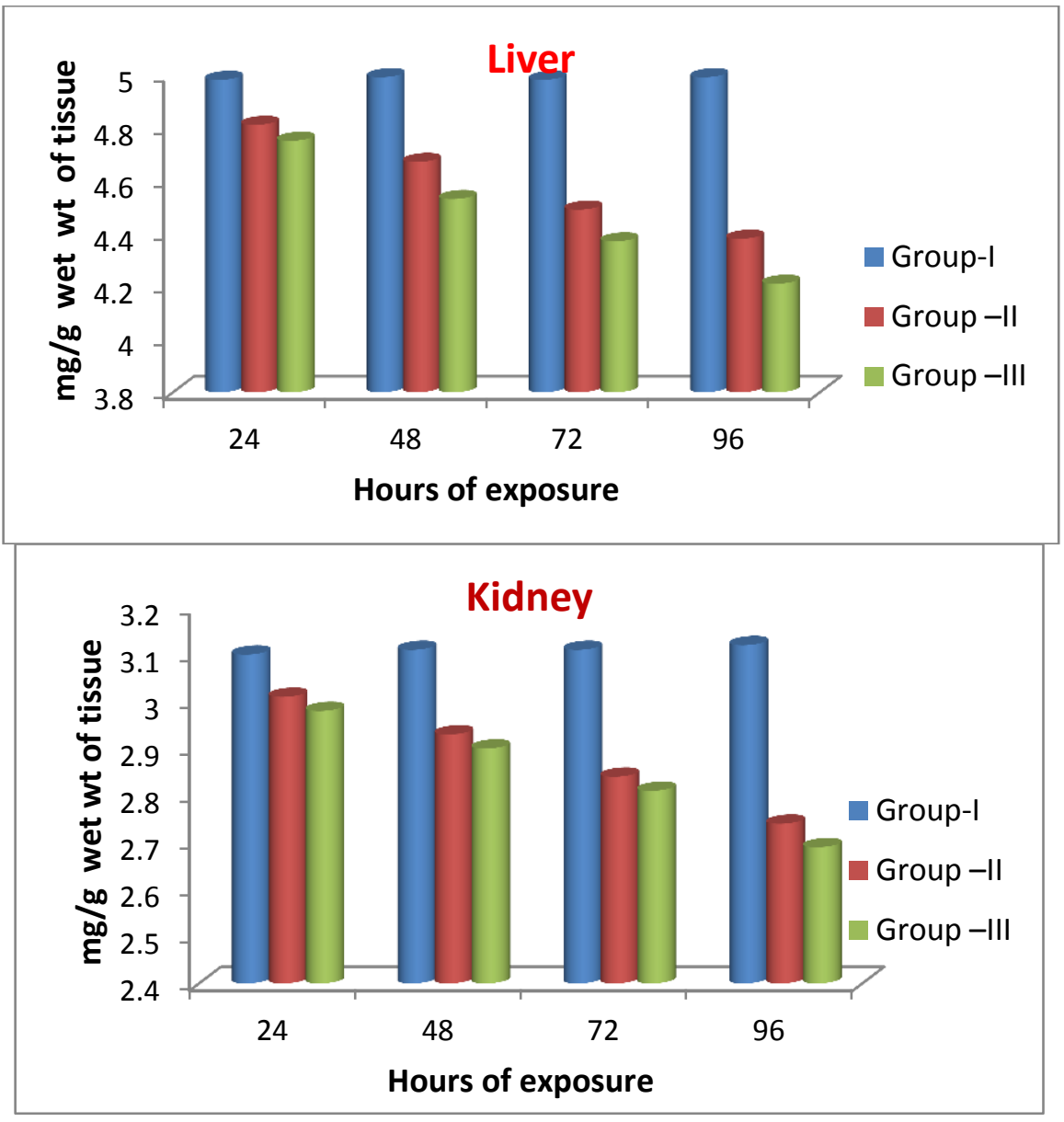

IV. DISCUSSION

In the present study there is significant decline in DNA content in the gill, liver and kidney tissues is observed, when the fish Gambusia affinis is exposed to the cyflthrin and fenvalerate . Pesticides appears as a potential inhibitor of DNA synthesis, which might result in reduction of RNA level. In fish, DNA repairing at a much lower speed than in mammals $[42,43]$. The toxicant decreases the DNA content due to inhibition of the enzymes in DNA synthesis . It is known that DNA functions as a primer in DNA and RNA polymerase reactions [44]., and the inhibition in DNA content can result in the inhibition of both DNA and RNA synthesis. Alteration in nucleic acid content leads to variations in protein profile [45,46]. The process of transcription control the activities of all the enzymes, when the transcription process is curtailed, mRNA and protein synthesis does not occur, due to which metabolism is impaired.

In the present study there is significant decline in RNA content in the gill, liver and kidney tissues is observed, when the fish Gambusia affinis is exposed to the cyflthrin and fenvalerate. The production of RNA plays a vital role in protein synthesis. The inhibition of RNA synthesis at transcription level may affect the protein content [47]. Significant decrease of RNA observed in the presen study. Pesticides may influence directly or modify DNA, other cellular process associated with the integrity of the genome. The pesticides interacts with the cellular DNA produces a variety of primary lesions such as single strand breaks, double strand breaks, DNA protein cross-link and damage to purine and pyrimidine bases [48].

Similar results were also reported by various investigations: (Cyprinus carpio); [49]. (Cirrhinus mrigala); [50]. (Channa punctatus); [51]. (Labeo rohita); [52]. (Colisa lalia); [53]. (Cirrhinus mrigala); [54]. (Channa striatus); [55]. (Channa punctatus); [56]. which substantiate the results of this study suggesting that cypermethrin is a potent inhibitor of nucleic acid synthesis even at sub lethal concentrations

Pesticides are electrophilic nature, the organophosphate (OP) compounds may attack many enzymes responsible for normal metabolic pathway. Protein level is depleted in tissues of fish because RNA plays significant role in protein synthesis [57]. The decrease in RNA level will affect the protein synthesis. [58]. reported similar results. Under stressed conditions animals 
require more energy to overcome the effect of pescticide. As a result, glucogenesis increases in comparsion with protein synthesis. The significant declines in RNA level in treated fish due to obstruction in RNA synthesis. Nissle bodies are rich in RNA, the swelling and chromatolysis of Nissle bodies is caused by pesticides. [59]. Decrease in protein synthesis, impairment of nucleic acid metabolism, the degradation of cells upon exposure to pesticides may be due to, resulting in the reduction in the DNA and RNA content.

\section{CONCLUSION}

It can be concluded that there is correlation between fish cyfluthrin and fenvalerate exposure and alterations in the nucleic acid contents in selected tissues. The DNA and RNA contents in tissues of gill, liver and kidney are gradually decreased in experimental fish in comparison with the control group. Decreases in the DNA content due to inhibition of the enzymes in DNA synthesis. The declines in RNA level in treated fish due to obstruction in RNA synthesis, resulting in the swelling and chromatolysis of Nissle bodies which are rich in RNA.

\section{REFERENCES}

[1]. Odum, E.P., 1971. Fundamentals of Ecology (W.B.Saunders), Toppanlo, Ltd., Tokyo, Japan.

[2]. Mathur , S.C. 1999. Future of Indian pesticides industry in next millennium. Pesticide Information. 24(4): 9-23.

[3]. Latner, A.L., 1975. In: Clinical biochemistry (Ed.: Contarow and Trumper). Saunders Company, Philadelphia, pp: $182-192$.

[4]. Venkataramana, G.V., P.N. Sandhya Rani and 14. P.S. Murthy, 2006. Impact of Malathion on the biochemical parameters of gobiid fish, Glossogobius giuris (Ham). J. Environ. Biol., 27: 119-122.

[5]. Anitha Susan, T.1999. Toxicity and effect of synthetic pyrethroid fenvalerate on the metabolism of the three Indian major carps Labeo rohita, Catla Catla and Cirrhinus mrigala (Ham). Ph.D. Thesis submitted to Nagarjuna University, A.P. India.

[6]. Rathod, D.S., M.V. Lokhande and V.S. Shembekar, 2009. Toxic impact of the biochemical composition of vital tissues of fish, Arias dussumieri. Shodh, Samiksha and Mulyankan, 2: 147-149.

[7]. Satyavardhan, K., 2010. Effect of fenvalerate TM on various tissues of Channa punctatus (Bloch). World Appl. Sci. J., 10 : 70-74.

[8]. Yaji, A.G., J. Auja, S.J. Oniye, J.A. Adakole and J.I. Usman, 2011. Effect of Cypermethrin on behavior and biochemical indices of freshwater fish, Oreochromis niloticus.

[9]. Farah MA, Atteq B, Ali MN and Ahmad W. Evaluation of genotoxicity of PCP and 2,4d by micronucleus test in freshwater fish, Channa punctatus. Ecotoxicol. Environ. Saf. (2003)54: 25-29.

[10]. Handy RD, Jha AN and Depledge MH. Biomarker approaches for ecotoxicological biomonitoring at different levels of biological organization. In Burden, F., McKelview, I., Forstner, U., Guenther, A (eds). Handbook of Environmental Monitoring, MCGraw Hill, New York (2001) 9.1-9.32.

[11]. EPA Pesticide Fact Sheet: Cyfluthrin. 1987. Fact Sheet No. 164 EXTOXNET. 2001. Cyfluthrin. Available online http://ace.orst.edu/cgi$\mathrm{bin} / \mathrm{mfs} / 01 / \mathrm{pips} / \mathrm{cyfluthr} . \mathrm{html}$

[12]. Adams K J, Chavasse DC, Mount DL, Carneiro IA, Curtis CF (2002) Comparative insecticidal power of three pyrethroids on netting. Med Vet Entomol 16:106-108.

[13]. Farm Chemical Handbook. 1993. Meister Publishing Company. Vol. 79.

[14]. Hamman, I. And R. Fuchs. 1981. ®Baythroid, a new insecticide. Pflanzenschutz- Nachrichten, 34(2):121-151.

[15]. Bradbury, S.P., Coats, J.R., 1989. Comparative toxicology of the pyrethroid insecticides. Rev. Environ. Contam. Toxicol. 108, $133-177$.

[16]. Benli, A.C.K., 2005. Investigation of acute toxicity of cyfluthrin on tilapia fry (Oreochromis niloticus L. 1758). Environ. Toxicol. Pharmacol. 20, 279282 .

[17]. Al-Makkawy, H.K., Madbouly, M.D., 1999. Persistence and accumulation of some organic insecticides in Nile water and fish. Resour. Conser. Recycl. 27, 105-115.

[18]. Wolansky, M.J., Harrill, J.A., 2008. Neurobehavioral toxicology of pyrethroid insecticides in adult animals: a critical review. Neurotoxicol. Teratol. 30, $55-78$.

[19]. Livingstone, D.R. 2001. Contaminant-stimulated reactive oxygen species production and oxidative damage in aquatic organisms. Bulletin of Marine Pollutants, 42: 656-666.

[20]. Kim, J., Chehade, J., Pinnas, J.L., Arshag, D., Mooradian, A.D., 2000. Effect of select antioxidants on malondialdehyde modification of proteins. Nutrition 16, 1079-1081.

[21]. Meister, R.T. 1995. Farm Chemicals Handbook '95. Meister Publishing Company. Willoughby, OH.

[22]. Veeraiah, K. and M.K. Durga Prasad: Study on the toxic effects of cypermethrin (technical) on organic constituents of freshwater fish. Labeo rohita (Hamilton). Proc. Acad. Environ. Biol., 7, 143-148(1998).

[23]. Tilak KS, Satyavardan K, Thathaji PB (2003). Biochemical changes induced by Fenvalerate in the freshwater fish Channa punctatus. J. Ecotoxicol. Environ. Monit., 13: 261-270.

[24]. Tripathi, G. and Verma, P. 2004. Fenvalerate induced changes in a catfish, Clarias batrachus: metabolic enzymes, RNA and protein. Comp. Biochem. Physiol., 138C: 75-79.

[25]. Sakr, S.A., S.M. Jamal and AI lail: Fenvalerate induced histopathological and histochemical changes in the Liver of the cat fish Clarias Gariepinus. J. Appl. Sci. Res., 1, 263-267 (2005).

[26]. Babu velmurugan, Mariadoss selvanayagam, Elif I. Cengiz and Erhan Unlu: The Effects of Fenvalerate on different tissues of fresh water fish Cirrhinus mrigala. J. Environ. Sci. Hlth., Part-B, 42, 157-163 (2007).

[27]. Ramaneswari, K. and L.M. Rao: Influence of endosulfan and monocrotophos exposure on the activity of NADPH cytochrome C reductase (NCCR) of Labeo rohita (Ham). J. Environ. Biol., 29, 183-185 (2008).

[28]. Majumdar, T.N. and A. Gupta: Acute toxicity of endosulfan and malathion on Chironomus ramosus (Insecta : Diptera : Chironomidae) from north Cachar hills, Assam, India. J. Environ. Biol., 30, 469-470 (2009).

[29]. Madan, V.K., Singh, R., Kumari, B., Naresh, J.S., Kathpal, T.S. 2000. "Dissipation of lindane and fenvalerate residues in chickpea (Cicer arietinum L.) under Indian climatic conditions". Ecotoxicology and Environmental Safety. 46: 163-166. 
[30]. Jagan, P., Reddy, M. S. and Rao, A. P. 1989. Effect of certain insecticides on the freshwater fish Cyprinus carpio carpio, L. Indian Journal of Environmental Biology, 10 (2): 135-138.

[31]. Tandon S.S., Srivastava P.P., Mukherjee S.C. and Saharan N., 2005. Acute toxicity of synthetic pyrethroids to Indian major carp, Catla catla L., Bull Environ Contam Toxicol, 74:60-613.

[32]. Singh, S. P., Chaudhary, R. and Gaur, K. K. 2007. A study of toxicity and behavior of freshwater fish, Channa punctatus (Bloch) after intoxication of carbamate and synthetic pyrethroid fenvalerate. J. Ecophysiol. Occup. Hlth. 7: 41-45.

[33]. Bradbury S.P., Coats J.R. and Mckim J.M., 1985. Differential toxicity and uptake of two fenvalerate formulations in fathead minnows (Pimephales promelas). Environ. Toxicol Chem., 4:533-541.

[34]. Chapman, R.A., Tu, C.M., Harris, C.R and Cole, C. 1981. Persistence of five pyrethroid insecticides on Rainbow trout. Bull. Environ. Contam. Toxicol. $26: 513-519$

[35]. Chapman, R.A. and Harris, C.R. 1981. Persistance of four pyrethroid insecticides in sterile and natural, mineral and organic soil, Bull. Environ. Contom. Toxicol, 20: 513-519.

[36]. Miyamoto J (1976): Degradation metabolism and toxicity of synthetic pyrethroid. Environmental Health Perspectives, 14,15-28.

[37]. Casida JE, Benett JP, Vickery BH, Gammon DW(1983): Mechanism of selective action of pyrethroid insecticide. Annual Review of Pharmacology and Toxicology, 23, 413-438.

[38]. Finney DT. Probit Analysis, 3rd edit. Cambridge University Press. London, 1971

[39]. Smith TM, Stratton GW (1986) Effects of synthetic pyrethroid insecticides on nontarget organisms. Res Rev 97:93-119.

[40]. Schneider, W.C. (1957) Determination of Nucleic Acids in Tissues by Pentose Analysis. In: Colowick, S.P. and Kaplan, W.O., Eds., Methods in Enzymology, Academic Press, New York, 680-684.

[41]. shodhganga.inflibnet.ac.in/bitstream/10603/69100/9/09_chapter\%202.pdf.

[42]. Walton D G, Acton A B and Stich H F (1984) DNA repair synthesis following exposure to chemical mutagens in primary liver, stomach and intestinal cells isolated from rainbow trout. Cancer Res. 44, 1120-1121.

[43]. Espina N G and Wesis P (1995) DNA repair in fish from polluted estuaries. Mar. Environ. Res. 39, 309-312.

[44]. Haqqi, T.M. and Adhami, U.M. 1979. Effect of apholate (ENT 26216, NSC 26812) on nucleic acids, total protein content and activity levels of aminotransferases (GOT, GPT), alkaline phosphatase and 5-nucleotidase in liver of male albino rats. Ind. J. Exp. Biol., 17: 488- 492.

[45]. Durairaj, S. and Selvarajan, V.R.1992. Influence of quinalphos, an Organophosphorous Pesticide, on the Biochemical constituents of the tissues of fish, Oreochromis mossambicus J.Environ. Biol. 13(3): p. 181-185.

[46]. Abou-Donia, M.B., Lapadul, D.M. and Carrington, C.D. 1988. Biochemical methods for assessment of neurotoxicity. In: Perspectives in basic and applied toxicology (Ed: B. Ballantyne). Butterworth \& Co. Ltd., London, 1-30.

[47]. Singh, K.S., Singh, S.K.S. and Yadav, R.P. 2010.Toxicological and biochemical alterations of cypermethrin (synthetic pyrethroid) against freshwater teleost Colisa fasciatus at different seasons. World J. Zool., 5(7): 25-32.

[48]. Van Loon, A.A.W.M., Groenendijk, R.H., Van DerShcanslohman, P.H.M. and Bran, R.A. 1991. Detectionof induced damage in DNA in human blood exposed to ionic radiation at biologically relevant doses. Int. J. Rad. Biol., 59: 651-660.

[49]. Gowri, B., Govindassamy, P. and Ramalingam, V. 2013. Influence of Cypermethrin on DNA and RNA Content in Different Organs of Freshwater Fish Cyprinus carpio. Iran. J. Pharm. Sci., 9(3): 1-10.

[50]. Veeraiah, K., Vivek, Ch., Srinivas Rao, P. and Venkatrao, G. 2013. Biochemical Changes induced by Cypermethrin (10\% EC), A Pyrethroid Compound in Sublethal and Lethal Concentrations to the Freshwater Fish Cirrhinus mrigala (Hamilton). J. Atom. Mol., 3(6): 625-634.

[51]. Thakur, A.C. and Kakde, V.R. 2012. Influence of Cypermethrin on DNA, RNA and RNA/DNA Ratio in Muscles of the Freshwater Fish Channa punctatus. Int. Interdisci. Res. Jour., 2: 38-42.

[52]. Tiwari, S., Tiwari, R. and Singh, A. 2012. Impact of Cypermethrin on Fingerlings of Common Edible Carp (Labeo rohita). The Scient. World Jour., 1: 17.

[53]. Singh, K.S., Singh, S.K.S. and Yadav, R.P. 2010.Toxicological and biochemical alterations of cypermethrin (synthetic pyrethroid) against freshwater teleost Colisa fasciatus at different seasons. World J. Zool., 5(7): 25-32.

[54]. Vasantharaja, C., Pugazhendy, C., Meenaambai, M., Prabukaran, S. and Dar, N.A. 2013. Properties of Cardiospermum halicacabum against the toxic effect of cypermethrin in the quantification of nucleic acids in the freshwater fish Cirrhinus mrigala (Hamilton). Int. Res.J. Pharm., 4(1): $280-283$.

[55]. Raksheskar, G.A. 2012. Influence of cypermethrin on DNA, RNA and RNA/DNA ratio in gills of the freshwater fish Channa striatus. Biosci. Disc., 3: 17-19.

[56]. Kumar, A., Sharma, B. and Pandey, R.S. 2007. Preliminary evaluation of the acute toxicity of cypermethrin and $\lambda$ - cyhalothrin to Channa punctatus. Bull. Environ. Contam. Toxicol., 79: 613- 616.

[57]. Tripathi, G, ., (2002): J. Environ Bio.vol-23, issue 2, pg 143-146.

[58]. Maruthanayagam, C, and Sharmila, G, (2004),Nature Env. Polln. Techn. Vol-3, issue 4, pg 491-494.

[59]. Tripathi, P. K,.. (2003), Asian fisheries Sci. issue 16, pg 349-359.

\section{AUTHORS PROFILE}

Dr S.Mohammed Ghouse M.Sc.,SLET., Ph.D, ., Zoology from Sri Krishna devaraya University, anantapurum, Andhra Pradesh, India in 1997,2000, 2006. He is currently working as a Reader in Department of Zoology , Osmania College, Kurnool since 1997. Life Member of The Indian Science Congress Association, Kolkata, India, Life Member of Indian Society of Cell Biology, India 2010, Life Member of ISCAP Tirupati, India -December 2010, Member of ISZS , CHINA 2010, Received State Teacher Award on $5^{\text {th }}$ September 2015 A.P Government fromhon.CM Chandrababu Naidu He has published more than 45 research papers in reputed National and International journals including Thomson Reuters (SCI \& Web of Science) and conferences also, available online and authored 3 books. His main research work focuses on Environmental biology, toxicology, avian biology etc. He has 22 years of teaching experience and 15 years of research experience. 